\title{
Pathogenicity of selected strains of entomopathogenic fungi to tetranychid mites (Tetranychidae) under laboratory conditions
}

\author{
Patogeniczność wybranych szczepów grzybów entomopatogenicznych \\ w stosunku do roztoczy z rodziny przędziorkowatych (Tetranychidae) \\ w warunkach laboratoryjnych
}

\author{
Cezary Tkaczuk*, Tomasz Krzyczkowski, Anna Majchrowska-Safaryan
}

Summary

The aim of the laboratory experiments was to assess the pathogenicity of selected strains of entomopathogenic fungi in relation to the two-spotted spider mite (Tetranychus urticae) and raspberry spider mite (Neotetranychus rubi). The tested fungal isolates, applied in the form of spraying with an aqueous spore suspension $\left(1 \times 10^{5} / \mathrm{ml}\right)$, were characterized by varying pathogenicity in relation to the mobile forms of spider mites. The highest mortality rate of pest was caused by Lecanicillium lecanii (75.4\%) and Beauveria bassiana (69.1\%) isolates. The lowest mortality of $T$. urticae was recorded when Isaria fumosorosea and Metarhizium flavoviride were applied. Increased concentration of fungal spores in the aqueous suspension from $1 \times 10^{5} / \mathrm{ml}$ to $1 \times 10^{7} / \mathrm{ml}$ did not significantly increase the number of infected individuals. Entomopathogenic fungus L. lecanii caused over $75 \%$ mortality of the raspberry spider mite.

Key words: phytophagous mites; Tetranychus urticae; Neotetranychus rubi; entomopathogenic fungi; pathogenicity

\section{Streszczenie}

Celem przeprowadzonych badań laboratoryjnych była ocena patogeniczności wybranych szczepów grzybów entomopatogenicznych w stosunku do przędziorka chmielowca (Tetranychus urticae) i przędziorka malinowca (Neotetranychus rubi). Testowane szczepy grzybów, zastosowane w formie opryskiwania wodną zawiesiną zarodników $\left(1 \times 10^{5} / \mathrm{ml}\right)$ charakteryzowały się zróżnicowaną patogenicznością w stosunku do form ruchomych przędziorka chmielowca. Najwyższą śmiertelność szkodnika spowodowały szczepy Lecanicillium lecanii $(75,4 \%)$ oraz Beauveria bassiana (69,1\%). Najniższą śmiertelność odnotowano w przypadku opryskiwania T. urticae wodną zawiesiną zarodników Isaria fumosorosea i Metarhizium flavoviride. Zwiększenie koncentracji zarodników grzybów w zawiesinie wodnej z $1 \times 10^{5} / \mathrm{ml}$ do $1 \times 10^{7} / \mathrm{ml}$ nie wpłynęło istotnie na zwiększenie liczby zainfekowanych osobników szkodnika. Owadobójczy grzyb L. lecanii powodował ponad 75\% śmiertelności przędziorka malinowca.

Słowa kluczowe: roślinożerne roztocze; Tetranychus urticae; Neotetranychus rubi; grzyby owadobójcze; patogeniczność

Uniwersytet Przyrodniczo-Humanistyczny w Siedlcach Wydział Przyrodniczy, Zakład Ochrony i Hodowli Roślin

Prusa 14, 08-110 Siedlce

*corresponding author: tkaczuk@uph.edu.pl 


\section{Wstęp / Introduction}

Roztocze fitofagiczne z rodziny przędziorkowatych (Tetranychidae) są bardzo specyficzną grupą agrofagów. Ich występowanie na roślinach uprawnych często zostaje niedostrzeżone do momentu, kiedy szkody powstające w wyniku ich żerowania prowadzą do dużych strat ekonomicznych. Ponadto szkodniki te wydają do kilkunastu pokoleń w ciągu sezonu wegetacyjnego i bardzo szybko wykształcają odporność na substancje czynne syntetycznych akarycydów.

Zadaniem współczesnej ochrony roślin jest zapewnienie skutecznych metod walki z agrofagami i dostarczanie rozwiązań, które wywierają możliwie najmniejszą presję na środowisko naturalne. Metoda biologiczna, w ramach której stosuje się między innymi mikroorganizmy, w tym grzyby entomopatogeniczne, jest jedną z najbardziej przyjaznych środowisku (Boczek i Lipa 1978; Lipa i wsp. 1998; Sosnowska 2013). Prowadzenie zwalczania biologicznego uzależnione jest od szeregu czynników biotycznych i abiotycznych oraz wymaga dogłębnych badań ekologicznych nad interakcjami zachodzącymi między środowiskiem $i$ jego poszczególnymi elementami.

Grzyby akaropatogeniczne z rodzajów Hirsutella czy Lecanicillium, reprezentujące anamorfy workowców (Hypocreales, Ascomycota) oraz niektóre gatunki owadomorkowców z rodzaju Neozygites (Neozygitales, Entomophthoromycota), są stałym komponentem naturalnie występujących populacji roztoczy roślinożernych, w tym ważnych z ekonomicznego punktu widzenia szkodników roślin uprawnych. Wywoływane przez nie mikozy tych pajęczaków często przybierają formy epizoocji prowadzących do ograniczenia ich liczebności do nieistotnego poziomu (Chandler i wsp. 2000; Miętkiewski i wsp. 2000; Van der Geest i wsp. 2000; Bałazy i wsp. 2008). Prowadzone w warunkach laboratoryjnych i szklarniowych badania wykazały wysoką patogeniczność wybranych izolatów grzybów $B e$ auveria bassiana i Metarhizium anisopliae w stosunku do przędziorka chmielowca (Tetranychus urticae) (Alves i wsp. 2002; Tamai i wsp. 2002; Chandler i wsp. 2005; Draganova i Simova 2010). Efektywne wykorzystanie patogenicznych grzybów w biologicznym zwalczaniu przędziorków w dużej mierze zależy od wyselekcjonowania najbardziej wirulentnych szczepów, które w przyszłości posłużą do produkcji bioakarycydów (Maniania i wsp. 2008).

Celem badań było określenie patogeniczności 5 gatunków grzybów entomopatogenicznych w stosunku do form ruchomych przędziorka chmielowca. Ponadto oceniono czy zwiększenie koncentracji zarodników dwóch najbardziej patogenicznych szczepów grzybów powoduje wzrost śmiertelności form ruchomych tego szkodnika oraz czy najbardziej wirulentne szczepy grzybów, czyli $B$. bassiana i Lecanicillium lecanii, w tym samym stopniu są patogeniczne dla form ruchomych przędziorka malinowca i przędziorka chmielowca.

\section{Materiały i metody / Materials and methods}

Doświadczenia wykonano w warunkach laboratoryjnych. W pierwszym eksperymencie do badań wytypowano pięć gatunków grzybów owadobójczych: B. bassiana, Isaria fumosorosea, Metarhizium flavoviride, M. anisopliae sensu lato i L. lecanii, zdeponowanych w kolekcji Zakładu Ochrony i Hodowli Roślin Uniwersytetu Przyrodniczo-Humanistycznego (UPH) w Siedlcach. Cztery pierwsze gatunki zostały wyizolowane z gleb pól uprawnych w okolicach Siedlec za pomocą metody owadów pułapkowych, a szczep L. lecanii został pozyskany z przędziorka malinowa (Neotetranychus rubi). Testy patogeniczności z zastosowaniem powyższych szczepów przeprowadzono na przędziorku chmielowcu, hodowanym na liściach fasoli i pochodzącym z wieloletniej hodowli Zakładu Ochrony i Hodowli Roślin UPH w Siedlcach.

Grzyby hodowano w szalkach Petriego na podłożu Sabourauda $\mathrm{w}$ termostacie, w temperaturze $25^{\circ} \mathrm{C}$ przez $14 \mathrm{dni}$. Zawiesinę wodną zarodników przygotowano zeskrobując skalpelem grzybnię i zarodniki z powierzchni kultur. Zarodniki grzybów zastosowano w koncentracji $1 \times 10^{5} / \mathrm{ml}$ po uprzednim ustaleniu ich liczby w roztworze przy pomocy hemocytometru Thoma. Szalki Petriego wykładano bibułą filtracyjną i lekko zwilżano ją wodą destylowaną w celu utrzymania odpowiedniej wilgotności. Następnie wykładano liście fasoli, na które wprowadzano po 50 form ruchomych przędziorka chmielowca. Liście z roztoczami opryskiwano przy użyciu ręcznego opryskiwacza ciśnieniowego o pojemności 11 (3 rozpylenia) wodnymi zawiesinami poszczególnych gatunków grzybów entomopatogenicznych $\mathrm{z}$ dodatkiem substancji zmniejszającej napięcie powierzchniowe wody (Triton X-100). Kontrolę stanowiły roztocze opryskiwane tylko wodą destylowaną z dodatkiem detergentu Triton X-100. Tak przygotowane szalki z roztoczami przetrzymywano $\mathrm{w}$ temperaturze $25^{\circ} \mathrm{C}$ przy oświetleniu przez 12 godzin na dobę. Obserwacje przeprowadzono po 4 i 8 dniach od opryskiwania, odnotowując osobniki żywe i martwe przędziorka. Martwe osobniki umieszczano w komorze klimatycznej na okres $10 \mathrm{dni}$, w celu potwierdzenia zainfekowania przez grzyby owadobójcze. Każdy wariant doświadczenia dla danego gatunku grzyba wykonano w 10 powtórzeniach.

Grzyby były identyfikowane na podstawie charakterystyki morfologicznej $\mathrm{z}$ wykorzystaniem standardowych kluczy (Humber 2012; Inglis i wsp. 2012). Ponieważ przy identyfikacji grzybów stosowano wyłącznie metody morfologiczne, gatunek $M$. anisopliae zdefiniowano w ujęciu sensu lato, gdyż jak wykazały najnowsze badania filogenetyczne oparte na sekwencji DNA (Bischoff i wsp. 2006, 2009), istnieje wiele gatunków grzybów w obrębie rodzaju Metarhizium, których rozróżnienie nie jest możliwe bez zastosowania metod molekularnych.

W kolejnym doświadczeniu zbadano wpływ dwóch różnych koncentracji zarodników $\left(1 \times 10^{5}\right.$ i $\left.1 \times 10^{7} / \mathrm{ml}\right)$ szcze- 
pów grzybów B. bassiana i L. lecanii na śmiertelność przędziorka chmielowca. Eksperyment przeprowadzono według metodyki opisanej powyżej.

W trzecim doświadczeniu laboratoryjnym przeprowadzono testy patogeniczności z zastosowaniem powyższych dwóch szczepów B. bassiana i L. lecanii (koncentracja zarodników $1 \times 10^{5} / \mathrm{ml}$ ) przeciwko przędziorkowi malinowcowi. Roztocze pochodziły z naturalnej populacji tego szkodnika występującej na liściach dziko rosnącej maliny w środowisku leśnym. Po kilkudniowym przetrzymaniu roztoczy w warunkach laboratoryjnych zostały one użyte do testów. Przędziorki nanoszono przed opryskiwaniem zawiesiną wodną zarodników na liście maliny w szalkach Petriego. Eksperyment przeprowadzono według opisanej wcześniej metodyki zastosowanej w testach z przędziorkiem chmielowcem.

Wyniki opracowano statystycznie za pomocą analizy wariancji (ANOVA). Istotność różnic pomiędzy średnimi oceniono za pomocą testu Tukeya przy poziomie istotności $\mathrm{p}=0,05$. Uzyskane średnie $\mathrm{z}$ analizy statystycznej przeliczono na \% śmiertelności. Wszystkie obliczenia w zakresie analizy statystycznej wykonano korzystając z pakietu statystycznego STATISTICA v. 12.

\section{Wyniki i dyskusja / Results and discussion}

Testowane szczepy grzybów, zastosowane w formie opryskiwania wodną zawiesiną zarodników $\left(1 \times 10^{5} / \mathrm{ml}\right)$ charakteryzowały się zróżnicowaną patogenicznością w stosunku do form ruchomych przędziorka chmielowca. Najwyższą śmiertelność roztoczy spowodował szczep L. lecanii (75,4\%) oraz B. bassiana (69,1\%). Najniższą śmiertelność odnotowano w przypadku opryskiwania T. urticae wodną zawiesiną zarodników I. fumosorosea (37,8\%) i M. flavoviride (43,7\%). Grzyb M. anisopliae sensu lato zainfekował prawie $60 \%$ roztoczy poddanych testom. Stwierdzono ponadto przypadki infekcji jaj przędziorka chmielowca przez ten gatunek grzyba, czego nie odnotowano w odniesieniu do pozostałych gatunków. Należy zwrócić uwagę na stosunkowo wysoką śmiertelność (ponad 20\%) osobników w kombinacji kontrolnej (tab. 1), co mogło być spowodowane dodaniem do wody substancji Triton X-100.

Chandler i wsp. (2005) testując w warunkach laboratoryjnych patogeniczność czterdziestu szczepów grzybów entomopatogenicznych, należących do sześciu rodzajów oraz trzech komercyjnych biopreparatów [Naturalis-L, oparty na szczepie $B$. bassiana, Mycar - Hirsutella thompsonii i Mycotal - Lecanicillium (= Verticillium) muscarium], stwierdzili dużą śmiertelność roztoczy wywołaną przez trzy izolaty: M. anisopliae, Hirsutella sp. i L. muscarium oraz wszystkie testowane bioinsektycydy komercyjne. Również Koike i wsp. (2005) wskazują na wysoką, ale jednocześnie zróżnicowaną patogeniczność czterech szczepów grzyba L. lecanii w stosunku do przędziorka chmielowca. Simova i Draganova (2003) odnotowały wysoką wirulencję szczepów B. bassiana i L. lecanii w stosunku do T. urticae, jedynie szczep grzyba Isaria farinosa charakteryzował się niskim potencjałem infekcyjnym w stosunku do tego roztocza. Późniejsze badania tych samych autorów potwierdziły wysoką, bo osiągającą $100 \%$ po czterech dniach od aplikacji, śmiertelność przędziorka chmielowca po zastosowaniu wodnej zawiesiny zarodników kilku szczepów grzyba $B$. bassiana w koncentracji 106/ml (Draganova i Simova 2010).

Wyniki dalszych testów, przeprowadzonych z dwoma najbardziej patogenicznymi gatunkami grzybów, tj. L. lecanii i $B$. bassiana wykazały, że zwiększenie koncentracji zarodników w zawiesinie wodnej z $1 \times 10^{5} / \mathrm{ml}$ do $1 \times 10^{7} / \mathrm{ml}$ wpłynęło nieznacznie na zwiększenie liczby zainfekowanych osobników T. urticae, jednak nie były to różnice istotne statystycznie (tab. 2).

Grzyb L. lecanii charakteryzował się również relatywnie wysoką patogenicznością $\mathrm{w}$ stosunku do przędziorka malinowca ( $N$. rubi). Śmiertelność form ruchomych roztocza po zastosowaniu wodnej zawiesiny zarodników tego grzyba w koncentracji $1 \times 10^{5} / \mathrm{ml}$ wynosiła ponad $75 \%$ (tab. 3). W przypadku szczepu grzyba B. bassiana była ona niższa i wynosiła 56,1\%. Wekesa i wsp. (2005) testując w warunkach laboratoryjnych 17 izolatow $M$. anisopliae i dwa izolaty B. bassiana przeciwko przędziorkowi Tetranychus evansi stwierdzili, że wszystkie szczepy były patogeniczne w stosunku do szkodnika, a powodowana przez nie śmiertelność wahała się od 22,1 do $82,6 \%$. Odnotowano większą podatność na infekcje form dorosłych niż larwalnych przędziorka. Ponadto oba gatunki grzybów w koncentracji $1 \times 10^{8}$ zarodników w $1 \mathrm{ml}$ zawiesiny powodowały powyżej 80\% śmiertelności jaj szkodnika.

Łącząc zabiegi zwalczania przędziorków za pomocą grzybów entomopatogenicznych i drapieżnych roztoczy należy pamiętać, że te ostatnie mogą być również podatne na infekcje grzybowe. Pytlak i wsp. (2014) testując wpływ różnych koncentracji zarodników grzybów entomopatogenicznych i nematopatogenicznych na przeżywalność drapieżnego roztocza Amblydromalus limonicus w warunkach laboratoryjnych stwierdzili, że grzyby B. bassiana i I. fumosorosea mogą powodować nawet do 80-90\% śmiertelności tego pożytecznego roztocza. Najmniej patogeniczne w stosunku do drapieżnika okazały się gatunki L. lecanii i Peacilomyces lilacinus. Maketon i wsp. (2008) badając skuteczność 12 szczepów grzybów entomopatogenicznych w zwalczaniu szkodliwego roztocza Polyphagotarsonemus latus w warunkach laboratoryjnych doszli do wniosku, że szczep $M$. anisopliae był najbardziej wirulentny w stosunku do pajęczaka. W testach używano zarodników patogena w koncentracji $2 \times 10^{8} / \mathrm{ml}$ cieczy. Średni czas uśmiercania 50\% populacji osobników dorosłych (LT50) wynosił 3,8 dnia, a larw - 2,4 dnia. Żaden z testowanych szczepów grzybów nie porażał jaj roztocza, co dało się zaobserwować w badaniach własnych w przypadku grzyba $M$. anisopliae. 
Tabela 1. Śmiertelność przędziorka chmielowca (Tetranychus urticae) spowodowana przez różne gatunki grzybów entomopatogenicznych [\%]

Table 1. Mortality of two-spotted spider mite (Tetranychus urticae) caused by various species of entomopathogenic fungi $[\%]$

\begin{tabular}{l|c|c}
\hline \multirow{2}{*}{$\begin{array}{c}\text { Gatunek grzyba } \\
\text { Fungal species }\end{array}$} & $\begin{array}{c}\text { Osobniki } \\
\text { zainfekowane } \\
\text { Infected } \\
\text { individuals }\end{array}$ & $\begin{array}{c}\text { Osobniki } \\
\text { martwe } \\
\text { Dead } \\
\text { individuals }\end{array}$ \\
\cline { 2 - 3 } & \multicolumn{2}{|c}{$[\%]$} \\
\hline Beauveria bassiana & $69,1 \mathrm{a}$ & 82,7 \\
\hline Isaria fumosorosea & $37,8 \mathrm{~b}$ & 56,0 \\
\hline Metarhizium flavoviride & $43,7 \mathrm{~b}$ & 56,5 \\
\hline Metarhizium anisopliae & $59,3 \mathrm{ab}$ & 71,2 \\
\hline Lecanicillium lecanii & $75,4 \mathrm{a}$ & 80,3 \\
\hline Kontrola-Control & $0 \mathrm{c}$ & 20,6 \\
\hline
\end{tabular}

Wartości oznaczone tymi samymi literami nie różnią się istotnie - Values indicated by the same letters are not significantly different

Tabela 2. Wpływ różnych koncentracji zarodników grzybów Lecanicillium lecanii i Beauveria bassiana na śmiertelność przędziorka chmielowca (Tetranychus urticae) [\%]

Table 2. Effect of various concentrations of Lecanicillium lecanii and Beauveria bassiana spores on mortality of two-spotted spider mite (Tetranychus urticae) [\%]

\begin{tabular}{c|c|c}
\hline \multirow{2}{*}{$\begin{array}{c}\text { Gatunek grzyba } \\
\text { Fungal species }\end{array}$} & \multicolumn{2}{|c}{$\begin{array}{c}\text { Koncentracja zarodników } \\
\text { Concentrations of spores }\end{array}$} \\
\cline { 2 - 3 } & {$\left[1 \times 10^{5} / \mathrm{ml}\right]$} & {$\left[1 \times 10^{7} / \mathrm{ml}\right]$} \\
\hline Beauveria bassiana & $69,1 \mathrm{a}$ & $76,8 \mathrm{a}$ \\
\hline Lecanicillium lecanii & $75,4 \mathrm{a}$ & $82,2 \mathrm{a}$ \\
\hline Kontrola - Control & 0 & $13,2 \mathrm{c}$ \\
\hline
\end{tabular}

Wartości oznaczone tymi samymi literami nie różnią się istotnie - Values indicated by the same letters are not significantly different

Fiedler i Sosnowska (2007) testując patogeniczność nicieniobójczego grzyba $P$. lilacinus w stosunku do kilku groźnych szkodników warzyw pod osłonami stwierdziły, że grzyb ten po siedmiu dniach od aplikacji spowodował śmiertelność $\mathrm{w}$ populacji przędziorka chmielowca na poziomie $70 \% \mathrm{w}$ warunkach laboratoryjnych i 60\% w warunkach szklarniowych.
Tabela 3. Śmiertelność przędziorka malinowca (Neotetranychus rubi) spowodowana przez grzyby Beauveria bassiana i Lecanicillium lecanii [\%]

Table 3. Mortality of raspberry spider mite (Neotetranychus rubi) caused by Beauveria bassiana and Lecanicillium lecanii $[\%]$

\begin{tabular}{c|c|c}
\hline \multirow{2}{*}{$\begin{array}{c}\text { Gatunek grzyba } \\
\text { Fungal species }\end{array}$} & $\begin{array}{c}\text { Osobniki } \\
\text { zainfekowane } \\
\text { Infected } \\
\text { individuals }\end{array}$ & $\begin{array}{c}\text { Osobniki } \\
\text { martwe } \\
\text { Dead } \\
\text { individuals }\end{array}$ \\
\cline { 2 - 3 } & \multicolumn{2}{|c}{$[\%]$} \\
\hline Beauveria bassiana & $56,1 \mathrm{a}$ & 68,6 \\
\hline Lecanicillium lecanii & $76,8 \mathrm{a}$ & 89,5 \\
\hline Kontrola - Control & $0 \mathrm{c}$ & 18,6 \\
\hline
\end{tabular}

Wartości oznaczone tymi samymi literami nie różnią się istotnie - Values indicated by the same letters are not significantly different

Jak wykazały przeprowadzone badania laboratoryjne, grzyb L. lecanii wykazał największą patogeniczność w stosunku do przędziorka chmielowca i przędziorka malinowca, spośród testowanych grzybów entomopatogenicznych, co wskazuje na potencjalne możliwości jego wykorzystania w biologicznym zwalczaniu obu szkodników.

\section{Wnioski / Conclusions}

1. Testowane szczepy grzybów charakteryzowały się zróżnicowaną patogenicznością w stosunku do form ruchomych przędziorka chmielowca. Najwyższą śmiertelność roztoczy spowodowały szczepy L. lecanii $(75,4 \%)$ oraz B. bassiana $(69,1 \%)$. Najniższą śmiertelność odnotowano w przypadku I. fumosorosea i M. flavoviride.

2. Zwiększenie koncentracji zarodników grzybów w zawiesinie wodnej z $1 \times 10^{5} / \mathrm{ml}$ do $1 \times 10^{7} / \mathrm{ml}$ nie wpłynęło istotnie na zwiększenie liczby zainfekowanych osobników T. urticae przez L. lecanii i B. bassiana.

3. Grzyb L. lecanii wykazał się największą patogenicznością w stosunku do przędziorka chmielowca i przędziorka malinowca, spośród testowanych grzybów entomopatogenicznych, co wskazuje na potencjalne możliwości jego wykorzystania w biologicznym zwalczaniu obu szkodników.

\section{Literatura / References}

Alves S.B., Rossi L.S., Lopes R.B., Tamai M.A., Pereira R.M. 2002. Beauveria bassiana yeast phase on agar medium and its pathogenicity against Diatraea saccharalis (Lepidoptera: Crambidae) and Tetranychus urticae (Acari: Tetranychidae). Journal of Invertebrate Pathology 81 (2): 70-77. DOI: 10.1016/S0022-2011(02)00147-7.

Bałazy S., Miętkiewski R., Tkaczuk C., Wegensteiner R., Wrzosek M. 2008. Diversity of acaropathogenic fungi in Poland and other European countries. Experimental and Applied Acarology 46 (1-4): 53-70. DOI: 10.1007/s10493-008-9207-1.

Bischoff J.F., Rehner S.A., Humber R.A. 2006. Metarhizium frigidum sp. nov.: a cryptic species of M. anisopliae and a member of the M. flavoviride complex. Mycologia 98 (5): 737-745. DOI: 10.1080/15572536.2006.11832645.

Bischoff J.F., Rehner S.A., Humber R.A. 2009. A multilocus phylogeny of the Metarhizium anisopliae lineage. Mycologia 101 (4): 512-530. DOI: 10.3852/07-202. 
Boczek J., Lipa J. 1978. Biologiczne metody walki ze szkodnikami roślin. PWN, Warszawa, 594 ss.

Chandler D., Davidson G., Jacobson R.J. 2005. Laboratory and glasshouse evaluation of entomopathogenic fungi against the two-spotted spider mite, Tetranychus urticae (Acari: Tetranychidae), on tomato, Lycopersicon esculentum. Biocontrol Science and Technology 15 (1): 37-54. DOI: 10.1080/09583150410001720617.

Chandler D., Davidson G., Pell J.K., Vall B.V., Shaw K., Sunderland K.D. 2000. Fungal biocontrol of acari. Biocontrol Science and Technology 10 (4): 357-384. DOI: 10.1080/09583150050114972.

Draganova S.A., Simova S.A. 2010. Susceptibility of Tetranychus utricae Koch. (Acari: Tetranychidae) to isolates of entomopathogenic fungus Beauveria bassiana. Pesticides and Phytomedicine 25 (1): 51-57. DOI: 10.2295/PIF1001051D.

Fiedler Ż., Sosnowska D. 2007. Nematophagous fungus Peacilomyces lilacinus (Thom) Samson is also a biological agent for control of greenhouse insects and mite pests. BioControl 52 (4): 547-558. DOI: 10.1007/s10526-006-9052-2.

Humber A.R. 2012. Identification of entomopathogenic fungi. Chapter VI. p. 151-187. In: "Manual of Techniques in Invertebrate Pathology" Second edition (L.A. Lacey, eds.). Academic Press Publ., London, UK, 484 pp.

Inglis G.D., Enkerli J., Goettel M.S. 2012. Laboratory techniques used for entomopathogenic fungi: Hypocreales. Chapter VII. p. 189-253. In: "Manual of Techniques in Invertebrate Pathology" Second edition (L.A. Lacey, eds.). Academic Press Publ., London, UK, $484 \mathrm{pp}$.

Koike M., Kodama T., Kikuchi A., Okabe M., Kuramoti K., Saito Y. 2005. Effects of Verticillium lecanii (Lecanicillium spp.) against twospotted spider mite, Tetranychus urticae and its natural enemy Phytoseiulus persimilis. p. 7-11. In: "Abstracts of 38th annual meeting of society of invertebrate pathology". Anchorage Publ., Alaska, USA.

Lipa J.J., Sosnowska D., Pruszyński S. 1998. Advances in biological control of Leptinotarsa decemlineata in Poland. OEPP/EPPO Bulletin 28 (4): 463-469. DOI: 10.1111/j.1365-2338.1998.tb00753.x.

Maketon M., Orosz-Coghlan P., Sinprasert J. 2008. Evaluation of Metarhizium anisopliae (Deuteromycota: Hyphomycetes) for control of broad mite Polyphagotarsonemus latus (Acari: Tarsonemidae) in mulberry. Experimental and Applied Acarology 46 (1-4): $157-167$. DOI: 10.1007/s10493-008-9153-y.

Maniania N.K., Bugeme D.M., Wekesa V.W., Delalibera I. Jr., Knapp M. 2008. Role of entomopathogenic fungi in the control of Tetranychus evansi and Tetranychus urticae (Acari: Tetranychidae), pests of horticultural crops. Experimental and Applied Acarology 46 (1-4): 259-274. DOI: 10.1007/s10493-008-9180-8.

Miętkiewski R., Bałazy S., Tkaczuk C. 2000. Mycopathogens of mites in Poland - A review. Biocontrol Science and Technology 10 (4): 459-465. DOI: 10.1080/09583150050115043.

Pytlak T., Fiedler Ż., Sosnowska D. 2014. Wpływ różnych koncentracji zarodników grzybów entomopatogenicznych i nematopatogenicznych na przeżywalność drapieżnego roztocza Amblydromalus limonicus (Garman \& McGregor). [The influence of different spore concentrations of entomopathogenic and nematopathogenic fungi on survival of the predatory mite Amblydromalus limonicus (Garman \& McGregor)]. Progress in Plant Protection 54 (4): 467-470. DOI: 10.14199/ppp-2014-079.

Simova S., Draganova S. 2003. Virulence of isolates of entomopathogenic fungi to Tetranychus urticae Koch (Tetranychidae, Acarina). Rasteniev'dni Nauki 40 (1): 87-90.

Sosnowska D. 2013. Postępy w badaniach i wykorzystanie grzybów pasożytniczych w integrowanej ochronie roślin. [Progress in research and the use of pathogenic fungi in integrated plant protection]. Progress in Plant Protection/Postępy w Ochronie Roślin 53 (4): 747-750. DOI: 10.14199/ppp-2013-018.

Tamai M.A., Alves S.B., de Almeida J.E.M., Faion M. 2002. Evaluation of entomopathogenic fungi for control of Tetranychus urticae Koch (Acari: Tetranychidae). [Avaliação de fungos entomopatogênicos para o controle de tetranychus urticae koch (Acari: Tetranychidae)]. Arquivos do Instituto Biológico 69 (3): 77-84.

Van der Geest L.P.S., Elliot S.L., Breeuwer J.A.J., Beerling E.A.M. 2000. Diseases of mites. Experimental and Applied Acarology 24 (7): 497-560. DOI: 10.1023/A:1026518418163.

Wekesa V.W., Maniania N.K., Knapp M., Boga H.I. 2005. Pathogenicity of Beauveria bassiana and Metarhizium anisopliae to the tobacco spider mite Tetranychus evansi. Experimental and Applied Acarology 36 (1-2): 41-50. DOI: 10.1007/s10493-005-0508-3. 